\title{
Transformational Leadership, Transactional Leadership and Employee performance
}

\author{
Dr. Fahad Bin Saad Algorabi Alharbi', Dr. Abdoulrahman Aljounaidi ${ }^{2}$ \\ Ministry of Education, Riyadh Alkhabra, Saudi Arabia ${ }^{1}$ \\ Department of Management, Al-Madinah International University, Kuala Lumpur, Malaysia. ${ }^{2}$ \\ *Corresponding author: Dr. Fahad Saad Soliaman Algorabi Alharbi. \\ Email address: Fahadclass1435@gmail.com
}

\begin{abstract}
This paper aims to investigate the relationship between independent and dependent variables. First relation between transformational leadership and employee performance. The second relation discuss in this paper between transactional leadership and employee performance. Researcher dependent on previous studies to conduct this research. Based on the previous studies reviewed and discussed, the results showed that the transformational leadership style has weak positive role effect on the employee performance inside organisations that they work in.

However, the result of previous studies on the transactional leadership style refers to the strong positive role on employee performance in organisations that they work in. Leaders have to enhance the role of transactional leadership styles in organisations that they manage them, to improve and develop the relationship between them and their subordinates in to increase the performance of their employee. Leaders should not follow the transformational leadership style because the results of previous studies are refer to a weak positive role on employee performance, and need more studies on transformational leadership to prove the role of it in different cultures and organisations. For further research in this scope, researcher recommended to conduct research in different cultures or organisations to determine leadership style has strong positive role on employee performance beside transactional leadership.
\end{abstract}

Keywords: Transformational leadership, Transactional leadership, employee performance 


\section{Introduction}

Leadership is one of the major study matters in Management (Odumeru \& Ifeanyi, 2013). In today's competitive environment, organizations are striving hard to meet their goals (Paracha et al., 2012). Leaders play significant role in organizations and help employees in achieving their goals and objectives. According to Northouse (2007), leadership is the ability of an individual to motivate a group towards the accomplishment of goals. It is a process in which an individual interacts with the workers of the organization, motivate them and helps them in achieving the target (Chaudhry \& Javed, 2012). Leaders are the source that enhance employee's performance and make them contented towards their jobs. Therefore, it has always been a controversial issue from many years (Islam et al., 2012).

It is essential for organizations to have a leader despite of all the contradictions about leadership role (Zenger \& Folkman, 2002). Leaders primarily affect group's performance and a group performance is dependent on leader. So, if leaders perform efficiently their job, the group will also perform the tasks efficiently (Drucker, 1996). Numerous researchers have studied the impacts and relationships of leadership style with employeeperformance (Paracha et al., 2012; Islam et al., 2012; Yiing \& Ahmad, 2009). Yiing and Ahmad (2009) conducted a research in Malaysian setting and examined leadership behavior and found its impact on employees' outcomes such as employees' performance and job satisfaction. Their study suggested that effective leadership is significant to employee performance and job satisfaction. Leaders that consider employees an essential asset, involve them in decisionmaking and identify their needs have significant relation with the employee performance and job satisfaction (Wang \& Rode, 2010).

Leaders are the key to determine the outcome of organisational goals and to set the tone for employee behaviour which may include promotion, appraisal and strategies (Brown \& Mitchell, 2010). Organisational leaders should encourage employees by leading by examples; they have the responsibility to define organizational norms and values, live up to expectations and encourage their followers to adopt same.

In this current article, we set out to extend the paradigm that involves leadership styles and employee performance. The paper discusses some of the following key issues:

1. To study a relationship between transformational leadership and employee performance. 
2. To study a relationship between transactional leadership and employee performance.

\section{Theoretical Background}

\subsection{Transformational Leadership}

Leadership plays a crucial role in causing changes necessary for effective management (Kim, 2012). It is a common action and is apparent in humans and animals (Bass, 2008). According to Kim (2012), leadership is a process and the ability of individuals to inspire a group of people through their vision towards the

accomplishment of their goals. Nahavandi (2002) stated that leadership is one of the managerial qualities of an organization that is effective to influence organizational performance and success. Various theories explain effectiveness of leadership. Among different types of leadership, transformational leadership and transactional leadership have been seen as strongly related with employee performance (Avolio، Bass, \& Jung, 1999; Kirkman. et al, 2009).

According to Burns (1978), transformational leaders motivate the followers by providing support to perform beyond expectations. Eeden, Cilliers and Deventer (2008) illustrated in their study that transformational leadership is not solely directive, rather it is related to the development and performance of followers. These leaders make a strong connection between followers and themselves by increasing their motivation and morality (Yukl, 2006). Bodla and Nawaz (2010) stated that transformational leaders manage organizations by inspiring, motivating and empowering their employees that results in organizational success. According to Robbins (2005), this leadership style includes four main components which are described below:

1) Idealized Influence: This component can be known as Charisma (Bass \& Riggio, 2006). Leaders inculcate confidence and motivation in followers in a way that followers admire them and try to emulate them (Northhouse, 2004).

2) Inspirational Motivation: It is the ability of transformational leaders in which a leader inspires the followers by arousing enthusiasm, pointing out positive outcomes and stimulating them (Kelloway, Barling, \&Helleur, 2000). 
3) Intellectual Stimulation: A characteristic in which leaders try to encourage the followers towards creativity and innovation. Transformational leader has the ability to motivate the followers to use creative and new ideas to rectify the issues (Bass \& Riggio, 2006).

4) Individualized Consideration: Transformational leaders act as a coach and mentor and pay attention to their followers' needs and feelings (Van Knippenberg \& Sitkin, 2013).

\subsection{Transactional Leadership}

According to Robbins (2005), transactional leadership is a style of leadership in which leaders manage the followers through rewards and punishment. It is a managerial leadership in which leader's prime responsibility is to focus on clarifying roles and tasks requirements (Dubrin, 2004). Miller (2011) argued that transactional leaders clarify roles and tasks to the followers and tell them what they need to do to reach their objectives. Sadeghi and Pihie (2012) demonstrated that transactional leadership theory is based on the exchange between leaders and followers. Hargis, Wyatt and Piotrowski (2001) stated that transactional leaders emphasize on extrinsic rewards for good work and give punishment for negative outcomes. This leadership approach has four components (Bass \& Avolio, 1994).

1) Contingent Reward: According to Odumeru and Ifeanyi (2013), contingent reward can be classified into two types. Contingent positive reinforcement and Contingent negative reinforcement. Contingent positive reinforcement is given when the defined goals are achieved on time or before time. This positive reinforcement is given in form of praise or rewards. Transactional leaders recognize followers' successful performance and reward them for positive output. On the other hand, contingent negative reinforcement is given when the set goals are not met, tasks are not accomplished and performance falls below standard.

2) Management by Exception-Active: Active management by exception means that leader observes followers performance, watches the deviations from the rules and regulations, anticipate problems and issues, take actions according to followers performance and makes corrections to resolve the problems (Odumeru \& Ifeanyi, 2013).

3) Management by Exception-Passive: Leaders who follow passive management by exception route do not involve in fixing the issues unless the issue is severe. Leaders keep themselves aside and intervene only if the problem becomes too serious (Odumeru \& Ifeanyi, 2013). 
4) Laissez - Faire: Laissez-Faire leadership is the characteristic of leaders in which they avoid making decisions and avoid taking responsibilities (Robbins, 2007). Leaders consider subordinates completely responsible for any decision and give subordinates complete freedom and power to make decisions about the work (Chaudhry \& Javed, 2012).

\subsection{Employee performance}

Kinicki and Kreitner (2007) describe that employee performance is the capacity of an individual to efficiently accomplish independent goals .Employees who are happy and satisfied with the management show high level of motivation and thus perform well to achieve organizational objectives (Kinicki \& Kreitner, 2007). Motowidlo and vanScotter (1994) described two dimensions of employee performance; Task performance and Contextual performance.

1) Task Performance: This dimension is also called technical job performance. In task performance, employees perform activities that are associated with servicing and development of organization's technical core. These activities include providing services to perform organizational technical tasks and procedures (Yiing \& Ahmad, 2009).

2) Contextual Performance: This dimension is not directly linked with job tasks but it strongly effects the organizations. It is also known as interpersonal job performance. Contextual performance consists of one's interpersonal skills and knowledge that assists the wider social environment (Yiing \& Ahmad, 2009). 


\section{Study Framework}

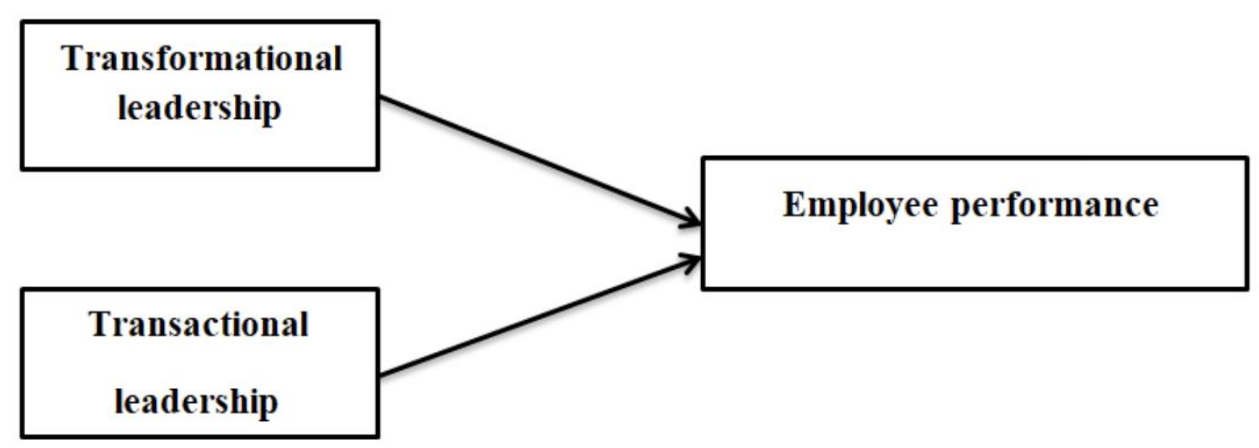

Research Framework

\section{Theoretical Framework}

\subsection{Transformational leadership and Employee performance}

Their research aims to determine the effect of leadership on employee performance at PT. Stella Satindo in Jakarta. According to (Rozi, et al,2020 ) the result of research refer to that leadership has a positive and significant effect on employee performance. One aim of his paper to prove and analyze the influence of transformational leadership towards employee performance. It reveals that transformational leadership has a significant effect on employee performance ( Atmojo, 2012). Paper aimed to measure the effect of transformational leadership and readiness for change on employee performance of the employee of a chemical industry. The results of this paper showed that transformational leadership has significant effect on the employee performance(Asbari, Hidayat \& Purwanto,2021).

\subsection{Transactional leadership and Employee performance}

The studying is about these two leadership styles having impact on employee's performance in FMCG industry of Pakistan. 
They found both leadership styles are having positive relation with employee performance but transactional leadership style has strongly positive correlation with the performance of the employees. (Kalsoom, Khan \& Zubair,2018). The purpose of this research is to determine that does leadership styles that is Transformational leadership style and transactional leadership style has an impact on employee performance. Result shows that transactional and transformational both are significantly positive associated with Employee performance however transactional leadership was more significant than transformational (Paracha et al,2012).

Researcher has a motivation to study the relationship between transformational leadership, transactional leadership and Employee performance due to previous studies that recommended to conduct more studies about these variables. Researcher wants to understand and analysis the relation between two important variables.

\section{Discuss}

According to (Al-Amin, 2017) study is to explore the relationship between transformational leadership and employee performance. The findings of this study indicate that transformational leadership behaviors are positively associated with employee performance. Paper aimed to measure the effect of transformational leadership and readiness for change on employee performance of the employee of a chemical industry. The results of this paper showed that transformational leadership has significant effect on the employee performance (Asbari, Hidayat \& Purwanto,2021).

The studying is about these two leadership styles having impact on employee's performance in FMCG industry of Pakistan. They found both leadership styles are having positive relation with employee performance but transactional leadership style has strongly positive correlation with the performance of the employees. (Kalsoom, Khan \& Zubair,2018). The purpose of this research is to determine that does leadership styles that is Transformational leadership style and transactional leadership style has an impact on employee performance. Result shows that transactional and transformational both are significantly positive associated with Employee performance however transactional leadership was more significant than transformational (Paracha et al,2012). 
From the results of previous studies, it became clear that transformational leadership has weak positive on employee performance. It means the transformational leadership has positive role on employee performance as mentioned in previous studies. On other hand, the transactional leadership has a greater and stronger positive role on employee performance than transformational leadership.

leader must strengthen the role of transformational leadership and transactional leadership in order for the employee performance to be according to what we expect and more, based on previous studies, leader should follow transactional leadership style because it has strong positive role on employee performance , and for future, researchers have to review what the cause of the negative and positive impact of leadership styles in different cultures on employee performance to determine the best style of leadership to follow it.

\section{Conclusion}

This paper investigate in the role of transformational leadership and transactional leadership on employee performance. The result of previous studies refer that transformational leadership has weak positive role on employee performance on other hand transactional leadership has strong positive role on employee performance. Leaders have to strengthen the role of transactional leadership to improve and develop the employee performance. For future research, recommended to conduct research in a quantities method in different cultures or organisations to determine leadership style has strong positive role on employee performance beside transactional leadership.

\section{References}

1. Achmad Rozi, Farida Agustin, Reni Hindriari, Dian Rostikawati and Irfan Rizka Akbar,(2020), The Effect Of Leadership On Employee Performance at PT. Stella Satindo In Jakarta, Humanities,Management and Science Proceedings) Vol.01, No.1, November 2020.

2. Anis Eliyana, Syamsul Ma'arif \& Muzakki, (2019), Job satisfaction and organizational commitment effect in the transformational leadership towards employee performance, European Research on Management and Business Economics 25 (2019) 144-150. 
3. Avolio, B., Bass, B. and Jung, D. (1999). Re-Examining the Components of Transformational and Transactional Leadership Using the Multifactor Leadership Questionnaire, Journal of Occupational and Organizational Psychology, 72(4), 441-462.

4. Bass, B. M. (2008). The Bass handbook of leadership: Theory, research, and managerial applications (4thed.). New York: Free Press.

5. Bass, B. M. and Avolio, B. J. (1994). Improving organizational effectiveness through transformational leadership. Thousand Oaks, CA: Sage.

6. Bass, B. M. and Riggio, R. E. (2006). Transformational leadership (2nd ed.). Mahwah, NJ: Lawrence Erlbaum Associates.

7. Bodla, M. A. and Nawaz, M. M. (2010). Transformational leadership style and its relationship with satisfaction.Interdisciplinary Journal of Contemporary Research in Business, 2(1), 370-381.

8. Brown, M.E. \& Mitchell, M.S. (2010). "Ethical and Unethical Leadership: Exploring New Avenue for Future Research", Business Ethics.

9. Burns, J. M. (1978). Leadership. New York: Harper \& Row.

10. Chaudhry, A. Q. and Javed, H. (2012). Impact of Transactional and Laissez Faire Leadership Style on Motivation. International Journal of Business and Social Science, 3(7), 258-264.

11. Drucker, P.F. (1996). The Executive in Action: Managing for Results Innovation and Entrepreneurship. Harper Collins, New York, NY.

12. Dubrin, A. J. (2004). Leadership: Research findings, practice, and skills. Boston, MA: Houghton Mifflin Company.

13. Hargis, M. B., Wyatt, J.D. and Piotrowski, C. (2001). Developing Leaders: Examining the Role of Transactional and Transformational Leadership across Contexts Business. Organization Development Journal 29 (3): 51-66.

14. Islam, T., Aamir, M., Ahmed, I. and Muhammad, S. K. (2012). The Impact of Transformational and Transactional Leadership Styles on the Motivation and Academic Performance of Students at University Level. Journal of Educational and Social Research, 2(2), 237- 244. 
15. Kelloway, E.K., Barling, J. and Helleur, J. (2000), Enhancing transformational leadership: the roles of training and feedback, Leadership \& Organization Development Journal, 21(3), 145-149.

16. Kim, H. (2012). Transformational leadership and organisational citizenship behavior in the public sector in South Korea: the mediating role of affective commitment. Local Government Studies, 38(6), 867-892.

17. Kirkman, B.L., Chen, G., Farh, J.L., Chen, Z.X. and Lowe, K.B. (2009) Individual Power Distance Orientation and Follower Reactions to Transformational Leaders: A Cross Level, Cross-Cultural Examination. Academy of Management Journal, 52, 744-764.

18. Kreitner, R. and Kinicki, A. (2007). Organizational Behavior(ed), N.Y., McGraw-Hill Irwin.

19. M. Umer Paracha, Adnan Qamar, Anam Mirza, Inam-ul-Hassan Waqas, (2012) Impact of Leadership Style (Transformational \& Transactional Leadership) On Employee Performance \& Mediating Role of Job Satisfaction" Study of Private School (Educator) In Pakistan,Global Journal of Management and Business Research,Volume 12 Issue 4 Version 1.0.

20. Marnis Atmojo, (2012), The Influence of Transformational Leadership on Job Satisfaction, Organizational Commitment, and Employee Performance, international research journal of business studies. Vol. 5 | No. 2.

21. Masduki Asbari, Dylmoon Hidayat \& Agus Purwanto, (2021),Managing Employee Performance: From Leadership to Readiness for Change, international journal of social and management studies (ijosmas)vol: 02 no. 01.

22. Md. Al-Amin ,) (2017) TRANSFORMATIONAL LEADERSHIP AND EMPLOYEE PERFORMANCE MEDIATING EFFECT OF EMPLOYEE ENGAGEMENT.North South Business Review, Volume 7, Number 2, June 2017, ISSN 1991-4938.

23. Miller, T. (2011). Integrity in transactional leadership. Wiley, 2011 (135), 35-44.

24. Motowidlo, S. J. and Van Scotter, J. R. (1994). Evidence that task performance should be distinguished from contextual performance. Journal of Applied Psychology, 79, 475- 480.

25. Nahavandi, A. (2002). The art and science of leadership.3rd ed. Upper Saddle River, NJ: Prentice Hall. 
26. Northouse, P. G. (2004). Leadership: Theory and practice (3rd ed.). Thousand Oaks, CA: Sage Publications.

27. Northouse, P. G. (2007). Leadership: theory and practice. 4th ed. Thousand Oaks, CA: Sage Publications.

28. Odumeru, J.A. and Ifeanyi, G.O. (2013), "Transformational vs transactional leadership theories: evidence in literature", International Review of Management and Business Research, Vol. 1 No. 2, 355-361.

29. Paracha, M. U., Qamar, A., Mirza, A., Hassan, I. and Waqas, H. (2012). Impact of leadership style (transformational \& transactional leadership) on employee performance $\&$ mediating role of job satisfaction: Study of private school (educator) in Pakistan. Global Journal of Management and Business Research, 12(4), 55-64.

30. Robbins, S. P. and Coulter, M. (2007) Management (9th ed.). London: Prentice- Hall.

31. Robbins, S.P. (2005). Organizational Behavior, 11th ed., Pearson Prentice-Hall, Englewood Cliffs, NJ.

32. Sadeghi, A. and Pihie, Z.A. (2012).Transformational leadership and its predictive effects on leadership effectiveness. International Journal of Business and Social Science, 3(7), 186-197.

33. Van Eeden, R., Cilliers, F. and Van Deventer, V. (2008). Leadership styles and associated personality traits: Support for the conceptualization of transactional and transformational leadership. South African Journal of Psychology, 38(2), 253-267.

34. Van Knippenberg, D. and Sitkin, S. B. (2013). A critical assessment of charismatic transformational leadership research: Back to the drawing board? The Academy of Management Annals, 7(1), 1-60.

35. Wang, P. and Rode, J. C. (2010), Transformational leadership and follower creativity: The moderating effects of identification with leader and organizational climate, Human Relations August, 63(8):1105-1128.

36. Yiing, L. H., Zaman, K.. and Ahmad, B. (2009). The moderating effects of organizational culture on the relationships between leadership behaviour and organizational commitment and between organizational commitment and job satisfaction and performance. Leadership \& Organization Development Journal, 30(1), 53-86. 
37. Yukl, G. (2006). Leadership in organizations, 6th edition. Upper Saddle River, NJ: Prentice Hall. Zenger, J. H. and Folkman, J., (2002). The Extraordinary Leader: Turning good managers into great leaders، The McGraw-Hill Companies Inc.

38. Zenger, J. H. and Folkman, J., (2002). The Extraordinary Leader: Turning good managers into great leaders, The McGraw-Hill Companies Inc.

39. Zohra Kalsoom, Mukaram Ali Khan \& Syed Sohaib Zubair, (2018),Impact of Transactional Leadership and Transformational Leadership on Employee Performance: A Case of FMCG Industry of Pakistan ,Industrial Engineering Letters , Vol.8, No.3, 2018.

Copyright $\odot 2021$ Dr. Fahad Bin Saad Algorabi Alharbi, Dr. Abdoulrahman Aljounaidi, AJRSP. This is an open-access article distributed under the terms of the Creative Commons Attribution License (CC BY NC).

Doi: doi.org/10.52132/Ajrsp.e.2021.294 